Vol-4, Issue-2, 2020 (IJEBAR)

E-ISSN: 2614-1280 P-ISSN 2622-4771

https://jurnal.stie-aas.ac.id/index.php/IJEBAR

\title{
EFFECTS OF ORGANIZATIONAL SUPPORT, SUPERVISOR SUPPORT AND COWORKERS INTERPERSONAL HELPING BEHAVIOR ON EMPLOYEE JOB SATISFACTION: A CASE STUDY IN BANGKOK, THAILAND
}

\author{
Arti Pandey, ${ }^{1)}$ Saifon Chairungruang ${ }^{2)}$ \\ International College, Rajamangala University of Technology Krungthep ${ }^{1,2)}$ \\ E-mail:saifon.c@mail.rmutk.ac.th
}

\begin{abstract}
Employees' job satisfaction would lead to more productive working environment in organizations. This study aims to examine the effects of employee's perception of organizational and supervisor supports as well as coworkers' interpersonal helping behavior on job satisfaction. The survey is collected data from a total of 50 employees, who works in both private and public organizations in Bangkok, Thailand. The findings show that perceived organizational support, perceived supervisor support and coworkers' interpersonal helping behavior have positive relationship with employee's job satisfaction. The suggestions are that, the organizations should keep the employees' satisfaction level by giving more feedback and reaction on their work apart from organizational support from supervisors. The supervisors also need to coach and help the subordinates in order to achieve their performance. The coworkers also play important role to their coworkers because good coworkers can create a good working environment. The coworkers need to help the coworkers who are still new in their roles, as well as can help when their coworkers suffer from job stress. Organizations should also inform all supervisors to support, coach and giving feedback on their subordinates' work in order to reduce their job stress and increase job satisfaction.
\end{abstract}

Keywords: Job satisfaction, Organizational support, Supervisor support, Coworkers' interpersonal helping behavior.

\section{Introduction}

Employees are the most valuable resources to the organization. They are the main element for all organizations to achieve their goal. Each employee has various attitudes toward their work, their coworkers, supervisors, subordinates and their income from the organizations (Kerdpitak \& Jermsittiparsert, 2020). How the individual employee experiences the work situation is what affects his or her job satisfaction and behavior: not the actual work situation. This becomes the reason why it is significant for the organization to study the psychological climate in order to better understand the employees' experiences and reactions to the organization.

Each employee has different attitudes and reactions toward the organization depend on how much support s/he has received from the overall organizational environment. Especially support from the organization, supervisor and coworkers are useful assets for increasing employees 
International Journal of Economics, Business and Accounting Research (IJEBAR)

Peer Reviewed - International Journal

Vol-4, Issue-2, 2020 (IJEBAR)

E-ISSN: 2614-1280 P-ISSN 2622-4771

https://jurnal.stie-aas.ac.id/index.php/IJEBAR

proper functioning in organizational life. For example, instrumental support by supervisors and coworkers in the form of giving information related to work and feedback on their works can be very useful for the employees who have just started their work in the organizations they can adjust themselves to the organizations and learn easily. Emotional support in the form of sympathy caring, sharing, comfort and encouragement can help employees' attachment to the organizations and happy with the organizations. Researchers found that instrumental and emotional assistance is a valuable asset to facilitate work and enhance job satisfaction (Mathieu et al., 2019; Mérida- López et al., 2019).

A strong support by the organization, supervisor and coworkers can contribute to the reduction of job-related stress, increase job satisfaction and increase perceived support. This study focuses on the employees' perception on organizational support, supervisor support and coworkers' interpersonal helping behavior whether it will affect their job satisfaction or not. Without the support from organization, supervisor and coworkers could have effects on employees' absenteeism, job satisfaction, work performance, employees' retention and commitment and turnover to employees working in all organizations. So, in order to find this out this research will emphasize on effect perceived organizational support, perceived supervisor support and coworkers' interpersonal helping behavior on job satisfaction. The result from this study will be useful for the organization to be considered the important of support from the organization, support from the supervisor and the coworkers from the view of employees and how these important to the employee's job satisfaction. With the result will help organizations, supervisors and coworkers understand the important of their support level to their employees and coworkers how it can affect and enhance the level of job satisfaction of their employees and their coworkers.

\section{Research Method}

In this study, rather than organization factors the job satisfaction based on the organizational member's exchange. In order to study job satisfaction, the conceptual framework is the main key to complete research framework for job satisfaction.

\subsection{Conceptual Framework}

The Figure 1 shows the conceptual framework of this research consists of independent and dependent variable. Independent variables consisted of the perceived organizational support, perceived supervisor support and coworkers' interpersonal helping behavior, dependent variable is job satisfaction.

Figure 1: Conceptual Framework of causes affecting the employee's job satisfaction adopt from Tangprasertkit (2002) 
International Journal of Economics, Business and Accounting Research (IJEBAR)

Peer Reviewed - International Journal

Vol-4, Issue-2, 2020 (IJEBAR)

E-ISSN: 2614-1280 P-ISSN 2622-4771

https://jurnal.stie-aas.ac.id/index.php/IJEBAR

\begin{tabular}{|l|l|l|}
\hline \multicolumn{1}{|c||}{ Independent Variables } & & Dependent Variable \\
\hline Perceived Organizational Support & & \\
\hline & & \\
\hline & & \\
\hline & & \\
\hline & & Job Satisfaction \\
\hline & & \\
\hline Perceived Supervisor Support & Control Variables \\
\hline & Age \\
\hline & Gender \\
\hline & Highest Education \\
\hline & Working Class \\
\hline & Job Position \\
\hline & & Workning Experiences \\
\hline
\end{tabular}

Hypothesis 1: There is a positive relationship between perceived organizational support and employee's job satisfaction.

Hypothesis 2: There is a positive relationship between perceived supervisor support and employee's job satisfaction.

Hypothesis 3: There is a positive relationship between co-workers' interpersonal helping behavior and employee's job satisfaction.

\subsection{Sample and data collection}

This research focuses on the sample of employees in Bangkok, Thailand. In order to get the various data from different occupations of respondent this research used snowball sampling technique. In this research relatives and friends of the researcher were asked to distribute the questionnaires to their colleagues at their workplace. Self-administered questionnaire survey was used to collect the data from respondents. The total distributed questionnaires were 50 questionnaires. All 50 questionnaires were returned back to the researcher the response rate is $100 \%$. Table 1 were reported the demographic and job characteristics of the participants.

Table 1: Descriptive statistics of the samples

Demographic factor Descriptive statistics

Age

21-25: $5(10 \%)$

26-30: $5(10 \%)$

31-35: 13 (26\%)

36-40: $10(20 \%)$

41-45: 7 (14\%)

46-50: $10(20 \%)$

Gender

Male: $30(60 \%)$

Female: $20(40 \%)$

Education

Diploma Degree (Vocation Course): 2 (4\%)

Bachelor's degree: 27 (54\%)

Master's degree: $19(38 \%)$

Doctoral degree: $2(4 \%)$

White Collar: 49 (98\%) 
International Journal of Economics, Business and Accounting Research (IJEBAR)

Peer Reviewed - International Journal

Vol-4, Issue-2, 2020 (IJEBAR)

E-ISSN: 2614-1280 P-ISSN 2622-4771

https://jurnal.stie-aas.ac.id/index.php/IJEBAR

$\begin{array}{ll} & \text { Blue Collar: } 1(2 \%) \\ \text { Job position } & \text { Junior staffs: } 10(20 \%) \\ & \text { Senior staffs: } 10(20 \%) \\ & \text { Lower-level managers: } 10(20 \%) \\ & \text { Middle-level manager: } 10(20 \%) \\ & \text { Senior-level manager: } 10(20 \%) \\ \text { Working experiences } & 1-5 \text { years: } 11(22 \%) \\ & \text { 6-10 years: } 13(26 \%) \\ & 11-15 \text { years: } 8(16 \%) \\ & 16-20 \text { years: } 10(20 \%) \\ & 21-25 \text { years: } 8(16 \%)\end{array}$

\subsection{Measures}

For this research there are three independents variables and one dependent variable. The independent variables are Perceived organizational support, Perceived supervisor support and Co-workers' interpersonal helping behavior. Dependent variable is Job satisfaction. In addition to the main independent variables this study will control for key factors that affect job satisfaction. These control factors are age, gender, educational level, working class, job position and job experiences.

Job satisfaction is measured using a scale developed by (Cammann, 1983). The scale consists of three items. These items are scored on a five-point rating scale, ranging from 1 (strongly disagree) to 5 (strongly agree).

Perceived organizational support is measured with the Survey of Perceived Organizational Support (SPOS) scale (Eisenberger et al., 1986). The short version of the SPOS is used of 5 items. These items are scored on a five-point rating scale, ranging from 1 (strongly disagree) to 5 (strongly agree).

Perceived supervisor support is measured with a slightly modified version of SPOS of Eisenberger et al. The short version of the SPOS is used of 5 items. These items are scored on a five-point rating scale, ranging from 1 (strongly disagree) to 5 (strongly agree).

Co-workers' interpersonal helping behavior is measured with the Interpersonal Helping (IH) scale which is part of (Moorman, 2016), validated and often used Organizational Citizenship Behavior (OCB) instrument. These items are scored on a five-point rating scale, ranging from 1 (strongly disagree) to 5 (strongly agree).

Age is measured is measured using an ordinal scale $(1=21-25 ; 2=26-30 ; 3=31-35 ; 4=36-$ $40 ; 5=41-45 ; 6=46-50$ ). Gender is measured as a dummy variable (females $=0$; males $=1$ ). Highest education level is measured using an ordinal scale $(1=$ diploma degree; $2=$ bachelor's degree; $3=$ master's degree; $4=$ doctoral degree). Working class is measured as a dummy variable $(1=$ white collars; $0=$ blue collars). Job position is measured using an ordinal scale $(1=$ junior staff; $2=$ senior staff; $3=$ junior manager; $4=$ middle level manager; $5=$ senior level manager). Working experiences is measured using an ordinal scale $(1=1-5$ years; $2=6-10$ years; $3=11$ 15years; 4=16-20years; 21-25years;). 
International Journal of Economics, Business and Accounting Research (IJEBAR)

Peer Reviewed - International Journal

Vol-4, Issue-2, 2020 (IJEBAR)

E-ISSN: 2614-1280 P-ISSN 2622-4771

https://jurnal.stie-aas.ac.id/index.php/IJEBAR

\subsection{Estimating technique}

Researcher of this paper used Ordinal Squares (OLS) regression to analyze the data. The analysis was performed using IBM SPSS Statistics version 23.

\section{Results and Discussion}

\subsection{Results}

Before testing the regression analysis, the reliability of concepts was tested by using multiple item scale and evaluated by using Cronbach alphas coefficient. Table2, shows that all Cronbach alphas coefficient exceed the widely suggested value of 0.7 . This means that the reliability of all constructs is satisfactory. Then, the scores of each multiple-item scale that belong to the same concept were averaged to create a summated scale in order to use for regression analysis.

Table 2: Results from reliability test

\begin{tabular}{|l|l|l|l|l|}
\hline Variables & $\begin{array}{l}\text { Perceived } \\
\text { Organizational } \\
\text { Support }\end{array}$ & $\begin{array}{l}\text { Perceived } \\
\text { Supervisor } \\
\text { Support }\end{array}$ & $\begin{array}{l}\text { Coworkers' } \\
\text { Interpersonal } \\
\text { Helping } \\
\text { Behavior }\end{array}$ & Job Satisfaction \\
\hline $\begin{array}{l}\text { Cronbach alphas } \\
\text { coefficient }\end{array}$ & 0.803 & 0.836 & 0.840 & 0.721 \\
\hline
\end{tabular}

In order to analyze the relationships between each variable the bivariate correlations among variables are analyzed using Pearson correlation coefficients.

Table 3: Correlation among variables

\begin{tabular}{|l|c|c|c|c|c||c|c|c|c|}
\hline Variables & $\mathbf{2}$ & $\mathbf{3}$ & $\mathbf{4}$ & $\mathbf{5}$ & $\mathbf{6}$ & $\mathbf{7}$ & $\mathbf{8}$ & $\mathbf{9}$ & $\mathbf{1 0}$ \\
\hline 1. Job satisfaction & $.603^{* *}$ & $.654^{* *}$ & $.472^{* *}$ & 0.191 & 0.204 & $.430^{*}$ & 0.255 & 0.464 & 0.171 \\
\hline 2.Perceived organizational support & 1 & $.728^{* *}$ & 0.32 & 0.136 & -0.016 & 0.333 & 0.17 & -0.418 & 0.232 \\
\hline 3.Perceived supervisor support & & 1 & $.528^{* *}$ & 0.02 & 0.1 & $.617^{* *}$ & 0.077 & 0.288 & -0.029 \\
\hline 4.Coworkers' interpersonal helping behavior & & & 1 & 0.027 & 0.034 & 0.324 & 0.025 & 0.098 & -0.033 \\
\hline 5.Age & & & & 1 & -0.256 & -0.216 & 0.091 & $.530^{* *}$ & 0.87 \\
\hline 6.Gender & & & & & 1 & 0.164 & -0.263 & 0 & -0.258 \\
\hline 7.Education & & & & & & 1 & -0.121 & 0.258 & 0.176 \\
\hline 8.Working class & & & & & & & 1 & 0.03 & 0.095 \\
\hline 9.Job position & & & & & & & & 1 & $.613^{* *}$ \\
\hline 10.Working experiences & & & & & & & & & 1 \\
\hline
\end{tabular}

Note $* \mathrm{p}<0.05, * * \mathrm{p}<0.01$ 
International Journal of Economics, Business and Accounting Research (IJEBAR)

Peer Reviewed - International Journal

Vol-4, Issue-2, 2020 (IJEBAR)

E-ISSN: 2614-1280 P-ISSN 2622-4771

https://jurnal.stie-aas.ac.id/index.php/IJEBAR

Table 4: Regression results

\begin{tabular}{|l|c|c|}
\hline \multicolumn{1}{|c|}{ Dependent variable is Job Satisfaction } & $\begin{array}{c}\text { Standardized Beta } \\
\text { Coefficient }\end{array}$ & VIF \\
\hline Hypothesized variable & & \\
$\quad$ Perceived organizational support (H1) & .255 & 3.137 \\
Perceived supervisor support (H2) & .133 & 4.794 \\
Coworkers' interpersonal helping behavior (H3) & .237 & 1.427 \\
Control variable & & \\
Age & .279 & 5.223 \\
Male dummy variable & .256 & 1.207 \\
Education & .149 & 2.236 \\
White collar workers dummy variable & .267 & 1.141 \\
Job position & .214 & 2.264 \\
Working experiences & -.183 & 6.028 \\
R-square & & \\
Adjusted r-square & .658 & \\
Number of observations & .504 & \\
& & \\
\hline
\end{tabular}

Results from the OLS regression analysis are presented in Table 4.

Hypothesis 1 predicts a positively relationship between perceived organizational support and job satisfaction. The result, as shown in the first column of Table 4. Even though it shows that these two variables are positively related, it is not statistically significant $\left({ }_{\beta}=.255 ; \mathrm{p}=.284\right)$. Therefore, hypothesis 1 is not supported.

Hypothesis 2 predicts a positively relationship between perceived supervisor support and job satisfaction. The result shows that even though it shows that these two variables are positively related, it is not statistically significant $\left({ }_{\beta}=.133 ; \mathrm{p}=.648\right)$. Therefore, hypothesis 2 is not supported.

Hypothesis 3 predicts a positively relationship between coworkers' interpersonal helping behavior and job satisfaction. The result shows that even though it shows that these two variables are positively related, it is not statistically significant $\left({ }_{\beta}=.237 ; \mathrm{p}=.146\right)$. Therefore, hypothesis 3 is not supported.

All control variables are positively related to job satisfaction but there is no control variable that has significantly relationship with job satisfaction.

The Variance Inflation Factor (VIF) statistics was evaluated. The VIF values range from 1.141 to 6.028, which were significantly below the critical value of 10 as suggested by Hair et al. (1995). This implies no serious multicollinearity issue in the analysis.

Figure 2: Regression results 
International Journal of Economics, Business and Accounting Research (IJEBAR)

Peer Reviewed - International Journal

Vol-4, Issue-2, 2020 (IJEBAR)

E-ISSN: 2614-1280 P-ISSN 2622-4771

https://jurnal.stie-aas.ac.id/index.php/IJEBAR

\begin{tabular}{|c|c|c|c|}
\hline Independent Variables & & Dependent Variable & Control Variables \\
\hline \multirow{3}{*}{ Perceived Organizational Support } & $+H_{1}: 0.255$ & & Age \\
\hline & & & 0.279 \\
\hline & H2: 0.133 & & Gender (Male=1) \\
\hline \multirow[t]{3}{*}{ Perceived Supervisor Support } & & Job Satisfaction & 0.256 \\
\hline & & & fighest Education \\
\hline & H33\% 0.237 & & 0.149 \\
\hline \multirow[t]{6}{*}{ Coworkers' Interpersonal Helping Behavior } & & & Working Class (White Collars $=1$ ) \\
\hline & & $R^{2} \quad=0.658$ & 0.267 \\
\hline & & Adj. $R^{2}=0.504$ & Job Position \\
\hline & & The Highest VIF $=6.028$ & 0.214 \\
\hline & & & Working Experiences \\
\hline & & & -0.183 \\
\hline
\end{tabular}

\subsection{Discussion}

The purpose of this research is to find whether the organizational support, supervisor support and coworkers' interpersonal helping behavior effect on employees' job satisfaction or not.

A growing body of evidence indicates that there exists a positive relationship between social support and job satisfaction. In a meta-analysis, support from leaders and co-workers was observed to have a positive effect on workers' reported job satisfaction. A meta-analysis, conducted by Self et al. (2020), found a positive relationship between co-worker support and job performance, job involvement, and organizational commitment among several other outcomes. Studies conducted to examine the influence of social support on productivity found that employees show higher rates of productivity when reporting higher levels of social support at work, especially by their supervisors. Eva et al. (2020) reported that perceived organizational support influenced managers' commitment to their organization, which in turn had a positive impact on employee development.

Perceived organizational support is defined as the degree to which employees believe that their organization values their contributions and cares about their well-being and fulfills socioemotional need (Caesens et al., 2019). The research on social exchange theory has shown that employee who feel they receive high levels of support from their organizations are more likely to perform better than those who do not (Cropanzano et al., 2017). When organizations admire their employees on their contribution and care on their wellbeing it would help employees to meet their needs in work life and more likely to be balanced between their work and their personal life (Giauque et al., 2019). Positive valuation by the organization also provides an indication that increased effort will be noted and rewarded. Perceived organizational support would increase employee's felt obligation to help the organization reach its objectives, their commitment to the organization, and their expectation that improved performance would be rewarded. Employees who perceived the organization are caring for their well-being are therefore, assumed to be more likely to reciprocate not only in engaging in various form of prosocial behavior directed toward the organization, but also by developing a stronger sense of job satisfaction (Richards et al., 2019). Singhapakdi et al. (2019) studied on perceived organizational support, job satisfaction and employee performance. The participants are employees and their immediate supervisors. Data analysis showed positive correlations of perceived organizational 
International Journal of Economics, Business and Accounting Research (IJEBAR)

Peer Reviewed - International Journal

Vol-4, Issue-2, 2020 (IJEBAR)

E-ISSN: 2614-1280 P-ISSN 2622-4771

https://jurnal.stie-aas.ac.id/index.php/IJEBAR

support and job satisfaction with work performance. These finding stress the important of perceived organizational support to the employees. However, this presented study found the relationship between organization support and job satisfaction is positive but not statistically significant.

Perceived supervisor support is defined as perceptions of supervisor work-life support as an employee's perception that their supervisor cares about his or her work - life well-being (Gordon et al., 2019a). Supportive supervisor behaviors include emotional support, instrumental support, role modeling behaviors and creative work-life management (Arasli \& Arici, 2019). When supervisor listens to the problem of the employees and try to understand the employees' emotion in order to let them feel that their supervisors care them it is called emotional support by supervisor. Instrumental support occurs when a supervisor tries to help and adjust employee's work-life demands on a daily basis or as it is needed (Giauque et al., 2019). For the third dimension of support would happen when supervisor actively demonstrate with the employee about how to balance their work-life behaviors on the job, support them and behave as the role model of the employee (Talukder et al., 2018). The fourth and final dimension of supervisor support is creative work- life management. Creative work- life management takes place when a supervisor rearranges a workday in order to enhance employee effectiveness on the job and off the job (Straub et al., 2018). Overall, supervisors play an important role in whether or not employees feel comfortable with balancing their work and life responsibilities. Gordon et al. (2019b) studied on supervisor support and career anchor impact on the career satisfaction of the hotel employees. The data analysis indicates that hotel employees find more satisfaction with their career when supervisor support is prominent and an adequate range of opportunities that satisfy career desires exist within the organization. These finding stress the important of perceived supervisor support to the employees. Unfortunately, same as the relationship between supervisor support and job satisfaction is positive but not statistically significant.

Coworkers' interpersonal helping behaviors can be defined as the extent that individuals view other workers at their organization as being helpful and supportive of them (Chae et al., 2019). Coworkers have the ability to define the social environment at work and they can have a large influence on whether or not an employee is able to balance his/her time between work and non-work life. According to Behson (2005) there are both informal and formal work-life supports within an organization. Informal supports (coworkers and supervisors) hold more weight in determining employee's job satisfaction compared to formal supports (policies). Attiq et al. (2017) studied on employee perceptions of perceived co-worker support and its effect on job satisfaction. The study shows that co-worker support was found to have a significant relationship with employees' job satisfaction. These findings emphasize the need for organizations to be aware of the importance of co-worker support. Like earlier findings in this presented study, the last is the relationship between coworkers' interpersonal helping behavior and job satisfaction also positive but not statistically significant. Even though all independent variables show positive relationship with job satisfaction but not statistically significant.

All these relationships between independent variables which are organizational support, supervisor support and coworkers' interpersonal helping behavior and dependent variable which is job satisfaction are not statistically significant. For correlation coefficient table that show the correlation between variables indicate that the organizational support, supervisor support and coworkers' interpersonal helping behavior has positive correlation coefficient with job 
International Journal of Economics, Business and Accounting Research (IJEBAR)

Peer Reviewed - International Journal

Vol-4, Issue-2, 2020 (IJEBAR)

E-ISSN: 2614-1280 P-ISSN 2622-4771

https://jurnal.stie-aas.ac.id/index.php/IJEBAR

satisfaction and can be supported statistically. These can be confident that the positive relationship between these variables do not just happen by chance.

\section{Conclusion}

The result from this research can also indicate that the organizational support, supervisor support and coworkers' interpersonal helping behavior are positively correlated to job satisfaction. The organizations should keep in touch with employees' satisfaction level by giving more feedback and reaction on their work apart from organizational support supervisors also need to coach and help the subordinates in order to achieve their performance. The coworkers also play important role to their coworkers because the good coworkers can create the good environment inside the work unit. The coworkers need to help the coworkers who still new on their work, should help them when their coworkers suffer from job stress. Organizations should also inform all supervisors to support, coach and giving feedback on their subordinates' work in order to reduce their job stress and increase job satisfaction.

Apart from the findings, there are some research weaknesses that need to be discussed. First is the data used in this research is presented from mainly on white collar employees so we can't conclude that white collar employees have more job satisfaction than blue collar employees because the research got only one blue collar employee as the sample. So, for future research should have more various level and background of sample in order to create more acceptable and accurate result. Second, is the result from factor analysis found that the questionnaire items of 2 concepts load into the same factor because they share high variation with other question items that belong to other concepts (Discriminant validity not satisfactory).

Thus, the items of same concept should not share to other questions in other concept so this is also the weakness of the result and the questions in those concepts should be changed for future study. Third, the correlation between independent variable with another independent variable should not be happened from the correlation coefficient result in this research found that perceived organizational support has positive correlation coefficient with coworkers' interpersonal helping behavior. Forth, the findings of this research couldn't be interpreted seriously in order to provide any practical implications.

\section{References}

Al Sabei, S. D., Labrague, L. J., Miner Ross, A., Karkada, S., Albashayreh, A., Al Masroori, F., \& Al Hashmi, N. (2020). Nursing Work Environment, Turnover Intention, Job Burnout, and Quality of Care: The Moderating Role of Job Satisfaction. Journal of Nursing Scholarship, 52, 95-104.

Arasli, H., \& Arici, H. E. (2019). Perceived supervisor support cure: Why and how to retain and reengage seasonal employees for the next season. Journal of East European Management Studies, 24(1), 61-88.

Attiq, S., Wahid, S., Javaid, N., Kanwal, M., \& Shah, H. J. (2017). The Impact of Employees' Core Self-Evaluation Personality Trait, Management Support, Co-worker Support on Job Satisfaction, and Innovative Work Behaviour. Pakistan Journal of Psychological Research, 32(1), 1-14. 
International Journal of Economics, Business and Accounting Research (IJEBAR)

Peer Reviewed - International Journal

Vol-4, Issue-2, 2020 (IJEBAR)

E-ISSN: 2614-1280 P-ISSN 2622-4771

https://jurnal.stie-aas.ac.id/index.php/IJEBAR

Behson, S. J. (2005). The Relative Contribution of Formal and Informal Organizational WorkFamily Support. Journal of Vocational Behavior, 66(3), 487-500.

Caesens, G., Stinglhamber, F., Demoulin, S., De Wilde, M., \& Mierop, A. (2019). Perceived organizational support and workplace conflict: The mediating role of failure-related trust. Frontiers in Psychology, Jan 9(9), 2704.

Cammann. (1983). Assessing organizational change: A guide to methods, measures, and practices. New York: Wiley.

Chae, H., Park, J., \& Choi, J. N. (2019). Two facets of conscientiousness and the knowledge sharing dilemmas in the workplace: Contrasting moderating functions of supervisor support and coworker support. Journal of Organizational behavior, 40(4), 387-399.

Chen, X., Ran, L., Zhang, Y., Yang, J., Yao, H., Zhu, S., \& Tan, X. (2019). Moderating role of job satisfaction on turnover intention and burnout among workers in primary care institutions: a cross-sectional study. BMC public health, 19(1), 1526.

Cropanzano, R., Anthony, E. L., Daniels, S. R., \& Hall, A. V. (2017). Social exchange theory: A critical review with theoretical remedies. Academy of Management Annals, 11(1), 479516.

Cross, C., \& Dundon, T. (2019). Social exchange theory, employment relations and human resource management. In Elgar Introduction to Theories of Human Resources and Employment Relations: Edward Elgar Publishing.

Eisenberger, R., Huntington, R., Hutchinson, S., \& Sowa, D. (1986). Perceived organizational support. Journal of Applied Psychology, 71(3), 500-507.

Eva, N., Newman, A., Miao, Q., Wang, D., \& Cooper, B. (2020). Antecedents of duty orientation and follower work behavior: The interactive effects of perceived organizational support and ethical leadership. Journal of Business Ethics, 161(3), 627639.

Giauque, D., Anderfuhren-Biget, S., \& Varone, F. (2019). Stress and turnover intents in international organizations: social support and work-life balance as resources. The International Journal of Human Resource Management, 30(5), 879-901.

Gordon, S., Adler, H., Day, J., \& Sydnor, S. (2019a). Perceived supervisor support: A study of select-service hotel employees. Journal of hospitality and Tourism Management, 1(38), 82-90.

Gordon, S., Adler, H., Day, J., \& Sydnor, S. (2019b). Perceived supervisor support: A study of select-service hotel employees. Journal of hospitality and Tourism Management, Mar. l(38), 82-90.

Kerdpitak, C., \& Jermsittiparsert, K. (2020). The Influence of Organizational Culture, Employee Commitment and Organization Citizen Behaviour on the HRM Practices: Mediating Role of Perceived Organization Support. Systematic Reviews in Pharmacy, 11(1), 407-415. 
International Journal of Economics, Business and Accounting Research (IJEBAR)

Peer Reviewed - International Journal

Vol-4, IsSue-2, 2020 (IJEBAR)

E-ISSN: 2614-1280 P-ISSN 2622-4771

https://jurnal.stie-aas.ac.id/index.php/IJEBAR

Lin, J. T., Chen, P. C., Su, C. Y., \& Chao, C. M. (2019). Behavioral intention to undertake health examinations: Transaction cost theory and social exchange theory. International Journal of Organizational Innovation, 11(4), 100-112.

Locke, E. A. (1976). The nature and causes of job satisfaction. In M. D. Dunnette (Ed.), Handbook of Industrial and Organizatioanal Psychology Chicageo: IL: Rand McNally.

Mathieu, M., Eschleman, K. J., \& Cheng, D. (2019). Meta-analytic and multiwave comparison of emotional support and instrumental support in the workplace. Journal of occupational health psychology, 24(3), 387.

Mérida López, S., Extremera, N., Quintana Orts, C., \& Rey, L. (2019). In pursuit of job satisfaction and happiness: Testing the interactive contribution of emotion regulation ability and workplace social support. Scandinavian journal of psychology 60(1), 59-66.

Mira, M., Choong, Y., \& Thim, C. (2019). The effect of HRM practices and employees' job satisfaction on employee performance. Management Science Letters, 9(6), 771-786.

Moorman, C., \& Day, G. S. (2016). Organizing for marketing excellence. Journal of Marketing, 80(6), 6-35.

Richards, K. A. R., Wilson, W. J., Holland, S. K., \& Haegele, J. A. (2019). The Relationships Among Perceived Organization Support, Resilience, Perceived Mattering, Emotional Exhaustion, and Job Satisfaction in Adapted Physical Educators. . Adapted Physical Activity Quarterly, 1(2019), 1-22.

Self, T. T., Gordon, S., \& Ghosh, A. (2020). Increasing Management Retention: The Mediating Role of Organizational Embeddedness on Coworker Support and Turnover Intention. International Journal of Hospitality \& Tourism Administration, 2020(Jan.24), 1-19.

Singhapakdi, A., Lee, D. J., Sirgy, M. J., Roh, H., Senasu, K., \& Grace, B. Y. (2019). Effects of perceived organizational CSR value and employee moral identity on job satisfaction: a study of business organizations in Thailand. Asian Journal of Business Ethics, 8(1), 5372.

Straub, C., Vinkenburg, C. J., Van Kleef, M., \& Hofmans, J. (2018). Effective HR implementation: the impact of supervisor support for policy use on employee perceptions and attitudes. The International Journal of Human Resource Management, 29(22), 31153135 .

Talukder, A. K. M., Vickers, M., \& Khan, A. (2018). Supervisor support and work-life balance. Personnel Review, 47(3), 727-744.

Tangprasertkij, R. (2002) A study of job satisfaction of hotel employees in Bangkok, Assumption University.

Yang, X. (2019). Social influence or personal attitudes? Understanding users' social network sites continuance intention. Kybernetes, 48(3), 424-437. 